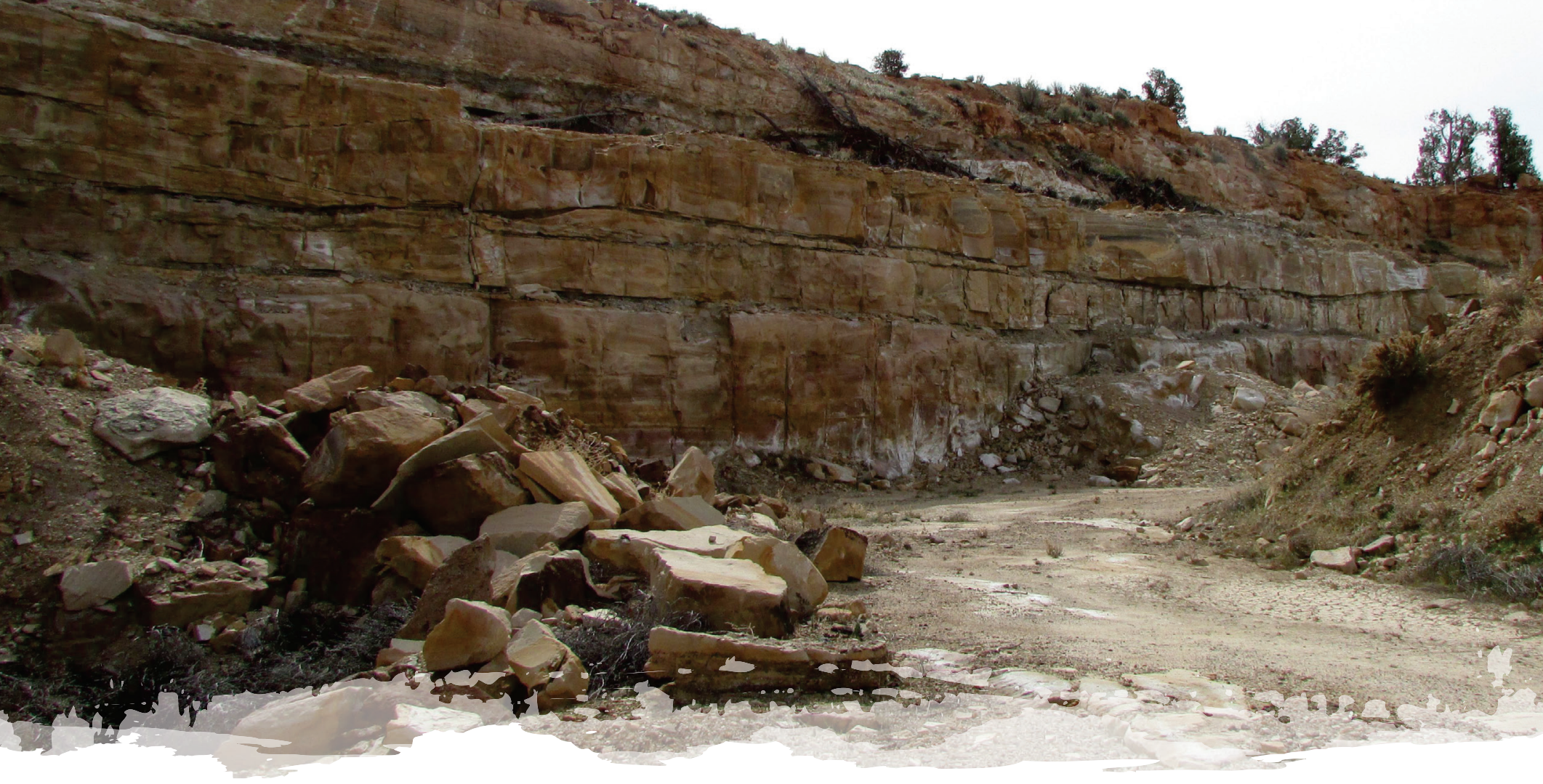

\title{
The Origin of Shinarump Wonderstone, Hildale, Washington County
}

Richard M. Kettler ${ }^{1}$ and David B. Loope ${ }^{1}$

${ }^{1}$ Earth \& Atmospheric Sciences, University of Nebraska

Lincoln, NE 68588-0340; rkettler1@unl.edu

\section{Utah Geosites \\ 2019}

Utah Geological Association Publication 48

M. Milligan, R.F. Biek, P. Inkenbrandt, and P. Nielsen, editors

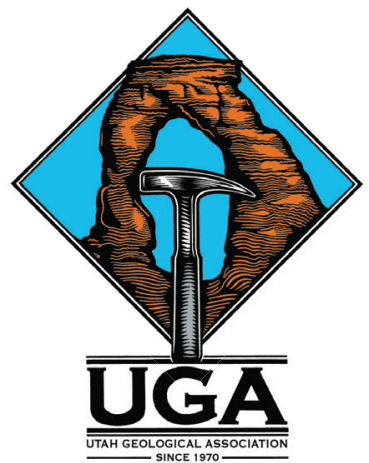




\section{INTRODUCTION}

Southern Utah's "wonderstone" is Shinarump sandstone, variably cemented and stained with iron oxide, forming intricate patterns reminiscent of landscapes. It is cut and sold as absorbent drink coasters and decorative objects, and is seen in rock shops across the country. The wonderstone pattern comprises thick bands of iron oxide mineralization that fills pore space (referred to as iron oxide cement or IOC) and more delicate bands of iron oxide mineralization that coats sand grains but does not fill pore space (referred to as iron oxide stain or IOS) (figure 1).

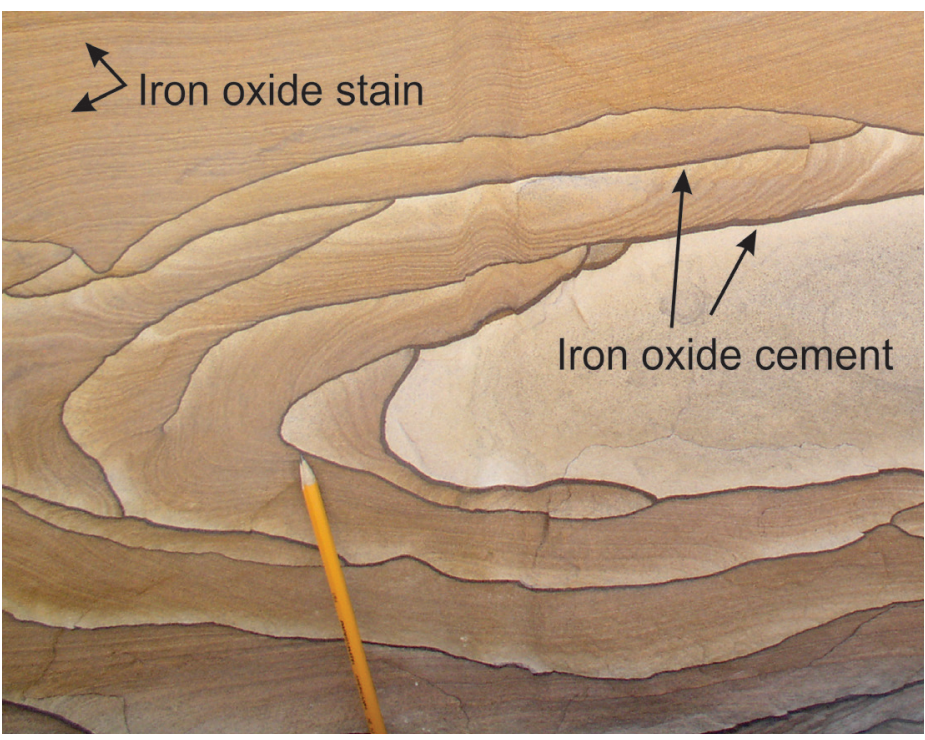

Figure 1. Example of wonderstone mineralization. The thick reddish-brown bands are iron-oxide cement whereas the wispy reddish-brown lines are iron-oxide stain.

The wonderstone pattern is of interest to geologists because it formed after the Shinarump sandstone was deposited from iron that was transported in aqueous solution. The iron that now resides in the cement and stain occurs as oxidized iron (iron-III) minerals (e.g., goethite and hematite). Significant amounts of iron-III can be transported in aqueous solution only under very unusual conditions. On the other hand, if an electron is added to iron-III, the resultant reduced iron (iron-II) can be transported readily in aqueous solutions. But iron-II forms a different group of minerals, typically pyrite $\left(\mathrm{FeS}_{2}\right)$ and siderite $\left(\mathrm{FeCO}_{3}\right)$ that do not have the characteristic red color of the wonderstone cement and stain. How was the iron that now resides in the wonderstone transported to its current location? What was the chemical mechanism for removing the iron from natural waters and fixing it as iron-III minerals?

The typical explanation for the wonderstone pattern is that the bands of iron oxide cement and stain are Liesegang bands. Liesegang bands were discovered originally by chemists and are a form of chemical self-organization that produces bands of insoluble material from the mixing of two solutions. The conventional interpretation is that when pyrite is exposed to oxygen-rich groundwa- ter the pyrite will dissolve, producing a strongly acidic, iron-rich solution. Iron-III will migrate in solution toward the source of oxygen. This aqueous iron-III will then precipitate as the solution is neutralized to form the Liesegang bands of iron oxide cement. This conventional interpretation was developed before geologists recognized the importance of microbes to processes that occur at low temperature.

Our interpretation is that iron was introduced to the rock as ironII shortly after sediment deposition and formed the mineral siderite. As the Colorado Plateau experienced uplift more oxygen-rich groundwaters invaded the Shinarump Sandstone. Iron-oxidizing bacteria thrive by transferring an electron from iron-II to oxygen to make iron-III. Energy is released during this transfer that the bacteria use to survive (in the same way that humans transfer electrons from the carbon in food to oxygen and survive using the energy released in those reactions). The IOC was produced through dissolution of siderite followed by oxidation of aqueous iron-II by microbes at a succession of oxidation-reduction interfaces. The IOC bands mark the position of interfaces where iron-oxidizing bacteria converted aqueous iron II to iron-III with a consequent precipitation of iron III oxide. We consider the iron oxide staining, on the other hand, to be Liesegang produced by the inter-diffusion of iron II and oxygen after the bands of cement were produced. See Kettler and others (2015) for a more complete description of the processes. The outcrops and blocks of wonderstone in this quarry provide a good summary of the evidence that falsifies the pyrite oxidation hypothesis in favor of our hypothesis.

\section{GPS LOCATIONS}

Quarry location: N 37.062482, W 113.130681. Intersection of 400 N. and Highway 59: N 37.083304, W 113.110919.

\section{Driving Instructions and Hiking Suggestions}

This quarry is located 9 miles $(14.5 \mathrm{~km})$ northwest of Hildale, in southernmost Utah (figure 2). Our directions begin at the intersection of 400N and Utah Highway 59 (State Street). As of 2019 this intersection is shown on Google Earth as the intersection of Little Creek Mesa Road with Highway 59. The sign marking the intersection reads $400 \mathrm{~N}$ and State Street. This intersection is located 1.6 highway miles $(2.6 \mathrm{~km})$ southeast of the intersection of Apple Valley Way and Utah State Highway 59 (site of a convenience store in Apple Valley), whereas the distance from the Utah-Arizona state line is 8.7 miles $(14 \mathrm{~km})$. Proceed west on $400 \mathrm{~N}$ for 0.25 miles $(0.4 \mathrm{~km})$ where the road will turn south. Proceed south on $7400 \mathrm{E}$ for 0.5 miles $(0.80 \mathrm{~km})$ to Little Creek Mesa Road and turn to the southwest. After 0.9 miles $(1.4 \mathrm{~km})$ on Little Creek Mesa Road, take the left fork and leave Little Creek Mesa Road. Drive an additional 0.25 miles $(0.4 \mathrm{~km})$ to the southwest and park. 


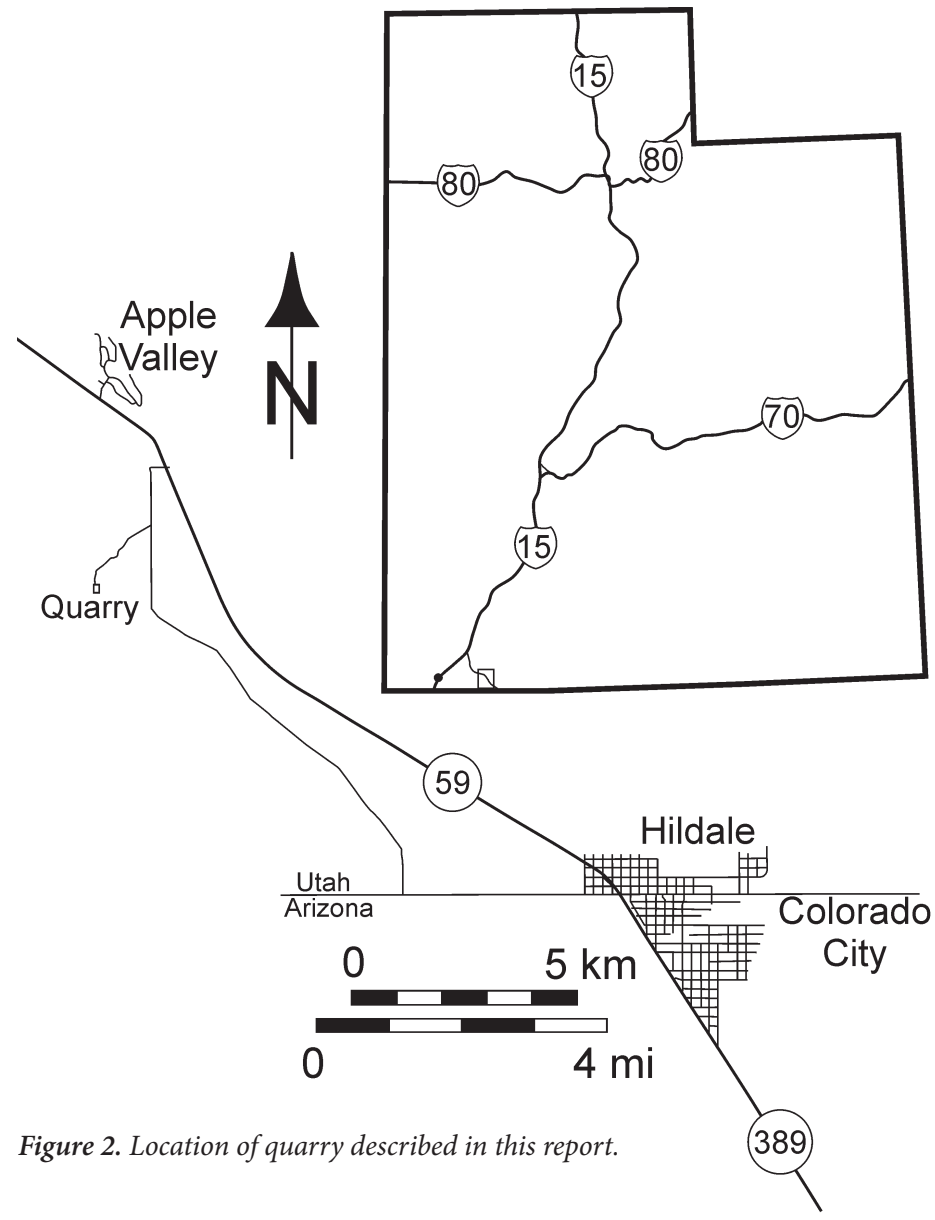

There are a number of wonderstone quarries located on both public and private lands in southern Utah. This particular quarry was operated by a company that sells absorbent, decorative, stone coasters. The quarry is still private property with public access (as of December 2019) administered by the Utah Department of Natural Resources (DNR) under the Walk-in-Access program (http://wildlife.utah.gov/walkinaccess/). The property is designated as MidnightPropWashington2 in the Walk-in-Access Program database. Visitors should adhere to all regulations prescribed by the Utah DNR. Visitors are required to obtain a walk-in access authorization number and present it if challenged. The authorization number is free of charge and available at http://wildlife.utah.gov/ walkinaccess/authorization.php.

All outcrops of interest are within 500 yards $(460 \mathrm{~m})$ of the parking area. The area is relatively free of hazards but visitors should be cognizant of hazards endemic to abandoned quarries (e.g., sharp edges on scrap, broken glass, loose rock, abandoned chemicals and equipment). Sturdy shoes, long pants, long sleeves, head and eye protection are recommended.

\section{GEOLOGIC CONTEXT}

The site is located in the Grand Staircase of the Colorado Plateau. The Grand Staircase comprises five step-like layers of sedimentary rock that are encountered as one moves north from the northern rim of the Grand Canyon to Bryce Canyon National Park. State Highway 59 connects Hildale and Hurricane, Utah, traversing the lowermost tread of the Grand Staircase (figures 2 and 3). To the northeast of the road are the Vermillion Cliffs of the Moenave and Kayenta Formations (figure 4), whereas southwest of the road the Moenkopi Formation of the Chocolate Cliffs faces south. The resistant Shinarump Member of the Chinle Formation forms the top of the Chocolate Cliffs. The Shinarump was deposited in an extensive braided stream system that flowed from southeast to northwest across the southern portion of North America (Dickinson and Gehrels, 2008). The unit locally has iron-oxide cementation, contains abundant fossil wood, and has produced significant amounts of uranium and copper mineralization. The beds in the area of the quarry are subhorizontal with regional dips of $1-2^{\circ}$ to the northeast.

\section{The Shinarump Sandstone and Iron-Oxide Mineralization}

Four different types of iron oxide mineralization can be observed in this quarry. (1) Iron oxide mineralization that fills pore space and forms bands that are $\mathrm{cm}$ thick. These bands of IOC may cross-cut or be parallel to bedding. (2) Between the bands of IOC it is typical to observe iron oxide stain that coats mineral grains but does not fill pore space. These finer features may give the rock a wood-grain appearance or mimic cross-bedding (figure 1). (3) Disseminated patches of iron oxide cement that locally assumes rhombic shapes. (4) Hollow concretions of iron oxide-cemented sandstone that may contain small fragments of mudstone. The accumulation of centimeter-thick masses of iron oxide cement is evidence that at least some of the iron was introduced to the rock as iron-II while in aqueous solution.

\section{Iron Oxide Mineralization is Controlled by the Presence of Fractures}

Excellent exposures in the southeastern quarry wall demonstrate that the Shinarump is a multistory sandstone with little preservation of floodplain muds (figure 5). Closer inspection reveals both disseminated and fracture-controlled iron-oxide mineralization. In the south wall of the quarry, a series of vertical joints fracture the Shinarump sandstone. Iron-oxide cement is concentrated in the sandstone immediately adjacent to these fractures but does not fill the fractures (figure 6). The relationship between the iron oxide cementation and fracturing is strong evidence that the fractures formed before the iron oxide mineralization. We interpret the accumulations along these fractures and those sub-parallel accumulations deeper in the sandstones to have been paleo-oxidation fronts. Reduced siderite dissolved and the resulting aqueous iron-II migrated to the oxidation front where microbes oxidized iron-II to iron-III. The iron-III immediately precipitated as insoluble iron-III oxide. In some blocks we can see a succession of these paleo-oxidation fronts that have been preserved by successive accumulations of iron oxide (figure 7). 

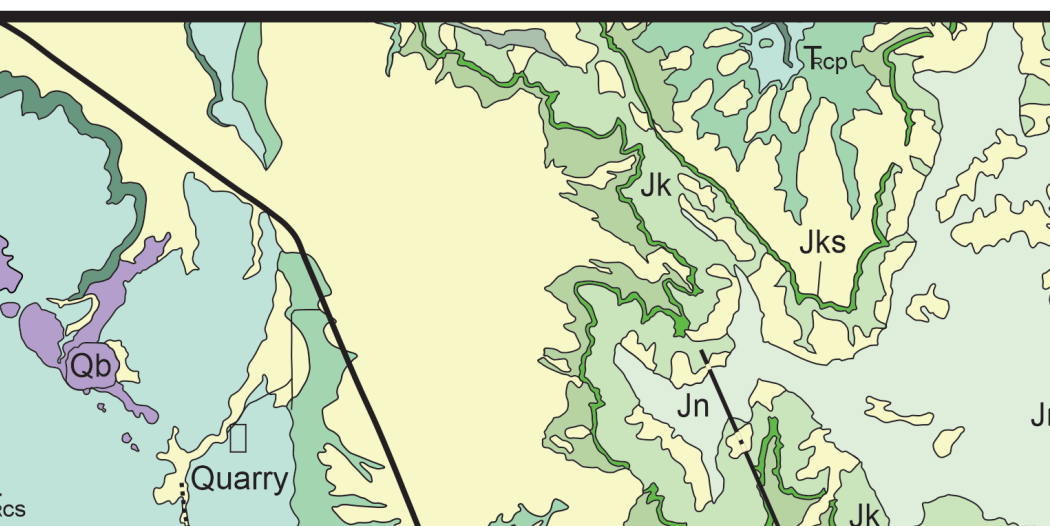

Jn

$\bigcup$ Geologic Contact

Fault, dotted where covered

Figure 3. Geologic map with quarry location marked. Geology modified from Biek and others (2010).

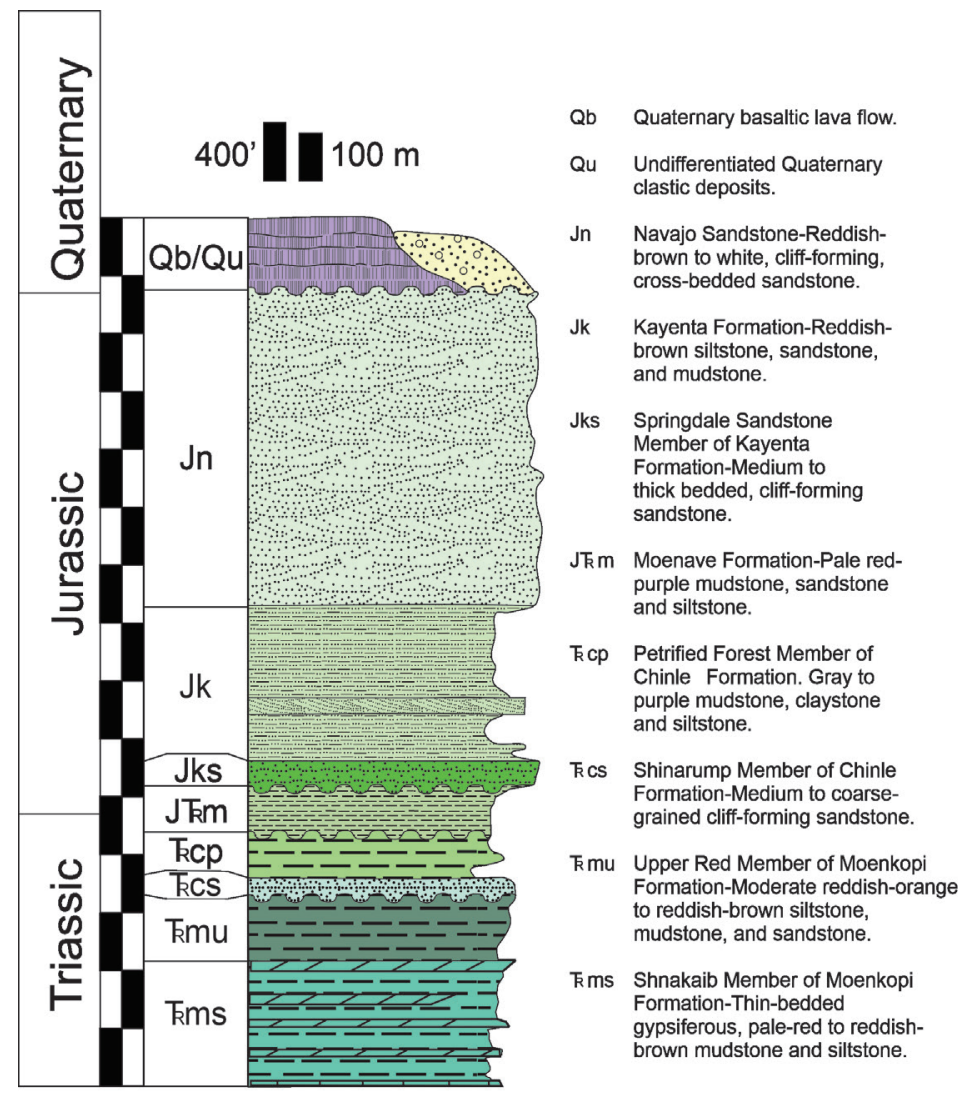

Figure 4. Mesozoic and Cenozoic stratigraphy. Quarry is located in the Shinarump Member of the Chinle Formation ( $\mathrm{R}$ CS). 


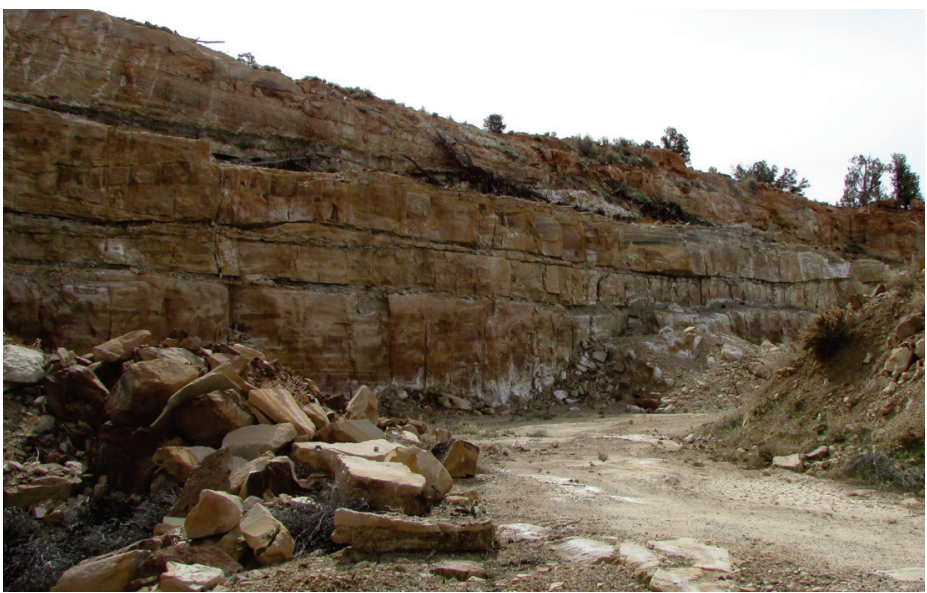

Figure 5. Multistory exposure of Shinarump sandstone in quarry with thin interbeds of less resistant mudstone.

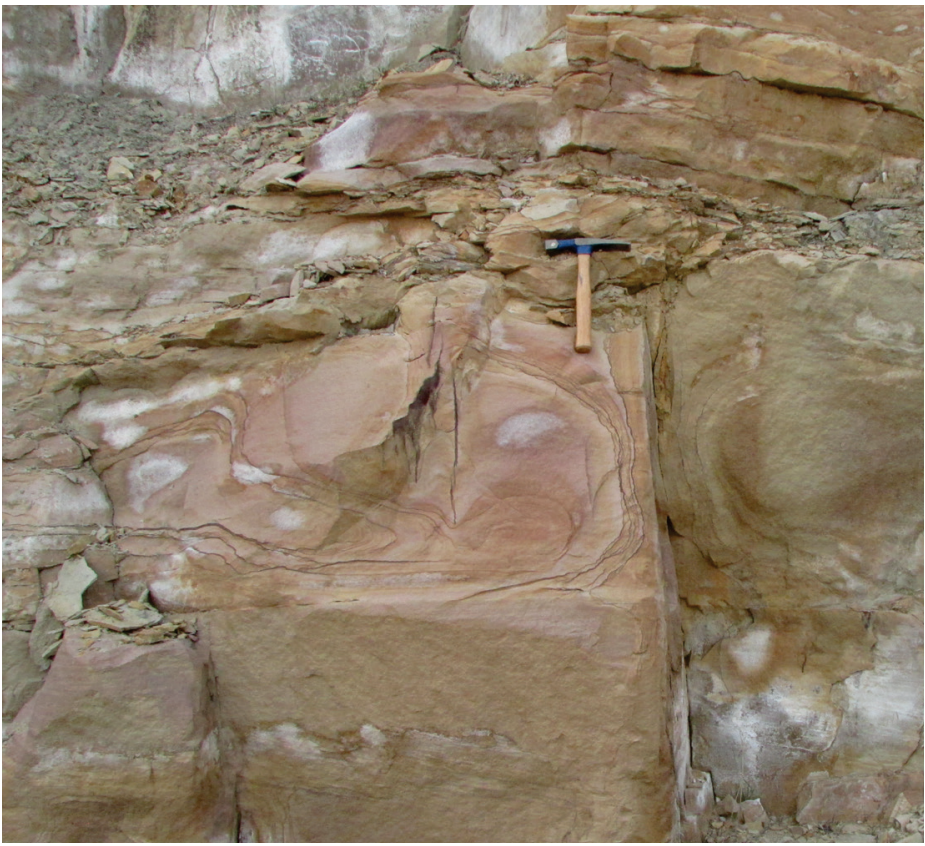

Figure 6. Shinarump sandstone exposure illustrating fracture control of iron-oxide mineralization. Note iron-oxide cement and staining parallel to vertical fracture right of hammer.

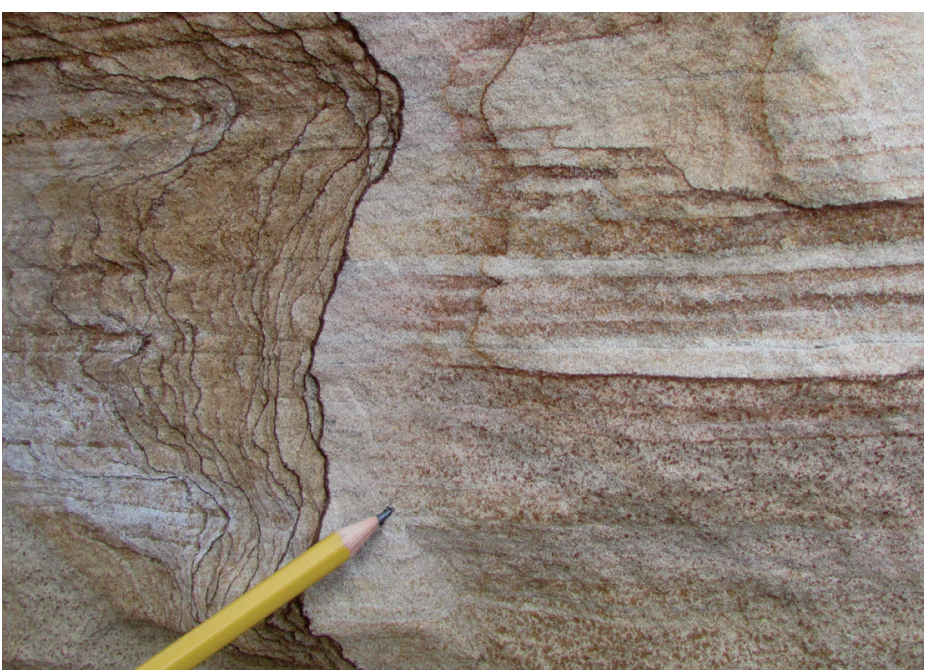

Figure 7. Wonderstone mineralization advancing (from left to right) on disseminated rhombohedral patches of iron oxide cement (small dark red dots on right half of photo) that are interpreted to be oxidized pseudomorphs after siderite.

\section{Siderite was the Most Likely Iron Oxide Precursor Mineral}

This quarry is unusual in that it is one of the few places where one can see both the wonderstone as well as evidence for the precursor iron mineralization. In the quarry walls and quarried blocks we observe disseminated patches of iron oxide (figure 8). Many of the disseminated patches have a rhombohedral form that we interpret to be iron oxide pseudomorphs after poikilotopic siderite $\left(\mathrm{FeCO}_{3}\right)$ cements. Siderite is a typical byproduct of organic matter fermentation during diagenesis, a process that is typical in stream sediments (Burgess and others, 2016). Most groundwaters that saturate river sediments contain small amounts of sulfate compared to the amount of sulfate found in ocean water. Whereas iron in oceanic sediment may be converted largely to pyrite, pyrite in river sediments tends to be ubiquitous (always present) but present in lesser abundance than siderite.

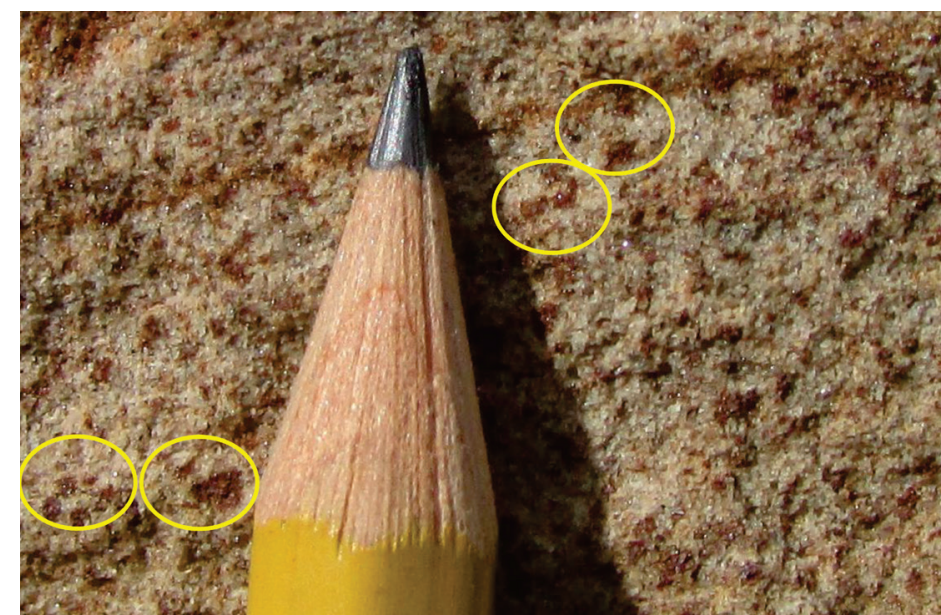

Figure 8. Rhombic patches of iron oxide cement (circled) interpreted to be pseudomorphs of iron oxide after siderite.

Sufficient sulfate was present here during diagenesis that small pyrite concretions formed and can be observed in the quarry face. It is important to note that the pyrite, which has a cubic crystal structure, is preserved whereas the precursor to the rhombohedral pseudomorphs has been oxidized. We interpret the morphologies and the continued preservation of pyrite as evidence that the rhombohedra did not have a pyrite precursor.

The final bit of evidence in support of a siderite precursor rather than pyrite is the presence of the bands of iron-oxide cement. Pyrite oxidation occurs when pyrite is attacked by aqueous iron III; the aqueous iron-III contacts the surface of the pyrite and an electron is transferred from sulfur in the pyrite to the iron. The iron-II that forms during this process is then oxidized back to iron-III by iron-oxidizing microbes. The rate of pyrite oxidation will therefore be slow unless the pyrite is bathed in an acidic, oxidizing fluid. The oxidizing environment is necessary to convert aqueous iron-II to iron-III. Because iron-III oxides are highly insoluble in neutral solutions, elevated concentrations of aqueous iron-III can exist only in acidic waters. The presence of the bands 
of iron oxide indicate that solid iron-III oxide precipitated upon oxidation. Iron-III that was trapped in mineral form as iron oxide would have been unavailable to attack pyrite. Siderite, on the other hand, will undergo simple dissolution to produce aqueous iron-II and carbonate. Subsequent oxidation of iron-II to iron-III and precipitation of iron-III oxides would not retard the dissolution of siderite, rather it would enhance it. The conversion of iron-II to iron-III removes the iron required to make siderite. Although the system will be driven to reach siderite saturation by dissolving more siderite, continued depletion of iron-II from the solution will prevent siderite saturation. Siderite is, therefore, doomed to dissolve in oxidizing systems

\section{Rattle Stones Occur with Other Coarse Clastics}

If one looks carefully in the quarry-particularly in areas where pebble and cobble-sized clasts are present in the thin Shinarump mudstone beds or at the base of sandstone channels-one can find ovoid concretions. Upon shaking these concretions, one can typically hear a rattling sound from the concretion interior. These concretions are known as rattle stones (hollow iron oxide concretions; Van der Burg, 1969; Loope and others, 2012; Burgess and others, 2016). Although very little of the floodplain mud is preserved, the presence of rattle stones is evidence that these muds contained abundant organic matter. Rattle stones are the product of early diagenetic cementation of mud by siderite. These siderite concretions may then be excavated and redeposited as the fluvial system migrates across the floodplain. During later oxidation, dissolution of siderite and microbially-mediated oxidation of ironII converts the siderite concretion to a rinded iron-oxide concretion. The siderite cement in the mudstone concretions is an early displacive cement. In other words the cement forms before the mud is converted to rock and pushes the mineral grains apart as it precipitates. The siderite concretion, therefore, consists of silt and clay-sized detritus that is floating in a mass of siderite cement. Dissolution of this cement and conversion to iron oxide leaves empty space that may contain fragments of mudstone. Thee mudstone fragments form the rattles within the rattlestone concretions.

\section{ACKNOWLEDGMENTS}

Our wonderstone research was supported in part by the NASA Nebraska Space Grant program. A careful review by Peter Mozley (New Mexico Tech) improved the manuscript.

\section{REFERENCES}

Antal, T., Droz, M., Mangin, J., Rácz, Z., and Zrinyi, M., 1998, Derivation of the Matalon-Packter law for Liesegang patterns: Journal of Chemical Physics, v. 109, no. 21, p. $9479-9486$ (doi: 10.1063/1.477609).

Biek, R.F., Rowley, P.D., Hayden, J.M., Hacker, D.B., Willis, G.C., Hintze, L.F., Anderson, R.E., and Brown, K.D., 2010, Geologic map of the St. George and east part of the Clover Mountains 30' x 60' quadrangles, Washington and Iron Counties, Utah: Utah Geological Survey Map 242 DM, 107 p., 3 plates, scale $1: 100,000$.

Burgess, D.T., Kettler, R.M., and Loope, D.B., 2016, The geologic context of wonderstone-a complex, outcrop-scaled pattern of iron-oxide cement: Journal of Sedimentary Research, v. 86, no. 5, p. 498-511 (doi: 10.2110/jsr.2016.35).

Disckinson, W.R., and Gehrels, G.E., 2008, U-Pb ages of detrital zircons in relation to paleogeography-Triassic paleodrainage networks and sediment dispersal across southwest Laurentia: Journal of Sedimentary Research, v. 78, no. 12, p. 745-764 (doi: 10.2110/jsr.2008.088).

Jablczynski, K., 1923, La formation rhythmique des précipités: Les anneaux de Liesegang, Bulletin de la Société Chimiquede France, v. 33, p. 1592-1597.

Kettler, R.M., Loope, D.B., Weber, K.A., and Niles, P.B., 2015, Life and Liesegang: outcrop-scale microbially-induced diagenetic structures and geochemical self-organization phenomena produced by oxidation of reduced iron: Astrobiology, v. 15, no. 8, p. 616-636 (doi: 10.1089/ast.2015.1305).

Loope, D.B., Kettler, R.M., Weber, K.A., Hinrichs, N.L., and Burgess, D.T., 2012, Rinded iron oxide concretions-hallmarks of altered siderite masses of both early and late diagenetic origin: Sedimentology, v. 59, no. 6, p. 1769-1781 (doi: 10.1111/j.13653091.2012.01325.x)

Van der Burg, W.J., 1969, The formation of rattle stones and the climatological factors which limited their distribution in the Dutch Pleistocene, 1. The formation of rattle stones: Paleogeography, Paleoclimatology, Paleoecology, v.6, p.105-124 (doi: 10.1016/0031-0182(69)90007-8). 